\title{
Evaluating the immune responses of mice to subcutaneous immunization with Helicobacter pylori urease B subunit
}

\author{
Peng Sun, Jia-Qi Wang ${ }^{*}$, Yu-Tao Zhang and Sheng-Guo Zhao
}

\begin{abstract}
Background: Helicobacter pylori, a gram-negative bacterial pathogen that expresses a strong urease activity, is associated with the development of gastroduodenal disease. Urease B subunit, one of the two structural subunits of urease, was expressed in E. coli BL21 (DE3) strain. The objective of this study was to evaluate the effects of Helicobacter pylori urease B subunit on the immune responses in mice by subcutaneous immunization.

Methods: The mice were immunized and boosted with Helicobacter pylori urease B subunit antigen subcutaneously three times with 2-wk intervals between the immunizations and boosters. The mice in the control group were immunized with PBS. The adjuvant group received PBS containing complete/incomplete freund's adjuvant identical to antigen group without Helicobacter pylori urease B subunit antigen. Four weeks after the final booster, all the mice were sacrificed. Blood was collected on d 0, 14, 28 and 56 before immunization, booster and sacrifice, respectively. Immediately after sacrifice, gastric liquid and spleen were collected for antibody and cytokine analyses.

Results: Urease B subunit increased the concentrations of serum and gastric anti-urease B antigen specific lgG, and the levels of interleukin-4 and interferon- $\gamma$ in splenocytes of the mice $(P<0.05)$.

Conclusions: This study demonstrated that recombinant urease B subunit can induce systemic and local immune responses in mice by subcutaneous immunization, which might be used as the effective component of vaccine against Helicobacter pylori.
\end{abstract}

Keywords: Antibody, Cytokines, Helicobacter pylori urease B subunit, Mice

\section{Introduction}

Helicobacter pylori, a gram-negative bacterial pathogen that expresses a strong urease activity, is associated with the development of chronic gastritis, peptic ulceration and gastric carcinoma [1]. It is one of the most common bacteria that infect people and more than half of the worldwide population has been infected. Although the application of $\mathrm{H} 2$ antagonists, antibiotics and recently proton pump inhibitor (PPI) can temporarily eradicate $H$. pylori infection, negative effects concerning antibiotic-resistant strains always limit the treatment [2-4]. In case of the difficulty in completely eradicating $H$. pylori from the upper gastrointestinal tract of the patients, utilization of a safe and effective vaccine

\footnotetext{
* Correspondence: jqwangcaas@gmail.com

State Key Laboratory of Animal Nutrition, Institute of Animal Science, Chinese Academy of Agricultural Sciences, No.2 Yuanmingyuan West Road, Beijing 100193, P. R. China
}

(c) 2014 Sun et al.; licensee BioMed Central Ltd. This is an Open Access article distributed under the terms of the Creative Commons Attribution License (http://creativecommons.org/licenses/by/2.0), which permits unrestricted use, distribution, and reproduction in any medium, provided the original work is properly credited. pylori infection [5-7].

Urease, a recognized virulence factor of $H$. pylori, is expressed broadly on the surface of $H$. pylori and contributes a lot to colonization of $H$. pylori [8,9]. The main function of urease is to degrade urea resulting in the release of ammonia. It has been postulated that urease consists of two structural subunits, urease A and B. Previous studies concerning immunology indicate that urease B subunit is highly immunogenic which has been regarded as one of the most prospectively protective antigens [10].

Mucosal immunization with the attenuated $H$. pylori or other bacteria containing urease or its subunits antigens via oral, nasal, rectal or other routes has previously been reported as effective ways to protect human or animals from H. pylori infection [11-13]. However, the immunogenicity of the foreign antigens via mucosal routes 
is usually poor without the utilization of adjuvant [13]. In case of the safety and side effects of oral administration of antigens and adjuvant that might cause diarrhea and threaten the health of the host, parenteral immunization has been recommended by various recent studies which suggest that parenteral immunization can also protect body against $H$. pylori infection as effectively as oral immunization because of the stimulation of relatively higher specific antibody concentrations $[1,11]$.

Here $H$. pylori urease B subunit was obtained after plasmid-encoded urease B from $H$. pylori was expressed in E. coli BL21 (DE3) strain. To evaluate the effects of $H$. pylori urease $\mathrm{B}$ subunit on the immune responses by subcutaneous immunization in mice, the indices of specific antibodies in serum and stomach as well as the splenocyte-secreted cytokines were determined in this study.

\section{Materials and methods}

\section{Establishment and characterization of purified $H$. pylori} urease $B$ subunit

E. coli SE 5000 containing the urease expression genes used in this study were kindly provided by H. T. Mobley from Department of Biology, Kilgore College, Kilgore, TX, USA. E. coli BL21 (DE3) strain was used as a recipient for the recombinant urease plasmid constructs that expressed urease $\mathrm{B}$ from the plasmid in which urease B genes from H. pylori had been cloned. After the E. coli BL21 (DE3) strain containing the urease $B$ genes was activated overnight at $37^{\circ} \mathrm{C}$, the bacteria were inoculated and cultured in Luria broth medium. Then the culture was induced by isopropyl- $\beta$-Dthiogalactopyranoside (IPTG; Sigma) and centrifuged at $6,000 \times g$ for $15 \mathrm{~min}$. Cells were harvested and catabolizated by lysozyme and nuclease. After sonication, the cell lysate was centrifuged at $12,000 \times g$ for $10 \mathrm{~min}$. Urease $B$ was expressed and obtained after washing with Buffer B (5\% triton, $50 \mathrm{~mol} / \mathrm{L}$ Tris $-\mathrm{HCl}, 50 \mathrm{mmol} / \mathrm{L} \mathrm{NaCl}$, and $5 \mathrm{mmol} / \mathrm{L}$ EDTA) and resolving in urea-Tris- $\mathrm{HCl}$ solution. Urease $\mathrm{B}$ antigen was purified by using a Ni-NTA kit (Novagen, Madison, WI) according to manufacturer's instructions. Sodium dodecyl sulfate polyacrylamide gel electrophoresis (SDS-PAGE) was applied to identify the expressed protein and the purity of urease $\mathrm{B}$ was measured by Bradford method (Bio-Rad, Hercules, CA).

\section{Mice}

All the mice used in this experiment were maintained in accordance with the principles of Chinese Academy of Agricultural Sciences Animal Care and Use Committee. Fifteen specific-pathogen-free, six-week-old female Kunming mice weighing 17-20 g were purchased from the Beijing Laboratory Animal Research Centre (Beijing, China) and divided into three treatments at random. Each treatment had five replicates with one mouse per replicate. All animals were housed in plastic cages in a mechanically ventilated nursery room where $12 \mathrm{~h}$ light: $12 \mathrm{~h}$ dark was set, and constant temperature remained at $23-25^{\circ} \mathrm{C}$ and relative humidity at $50-60 \%$. All the mice had sterilized commercial chow (Beijing Laboratory Animal Research Centre) and water ad libitum under pathogen-free conditions.

\section{Immunization procedures and sample collection}

Three groups of 5 mice were used as control, adjuvant and antigen. After seven days of adaptation, mice were immunized and boosted subcutaneously three times with 2-wk intervals between the immunizations and booster. H. pylori urease B subunit antigen was mixed with complete/incomplete freund's adjuvant (v/v, 1:1), and $40 \mu \mathrm{g}$ of H. pylori urease B subunit antigen in a volume of $100 \mu \mathrm{L}$ of emulsion was injected into the lower back of the antigenic mice on $\mathrm{d} 0$ and 14. The mice in the control group were immunized with PBS. The adjuvant group received PBS containing complete/incomplete freund's adjuvant identical to antigen group without $H$. pylori urease B subunit antigen. The mice were boosted with $80 \mu \mathrm{g}$ of urease B antigen and incomplete freund's adjuvant on d 28. Blood was collected retro-orbitally before immunization and booster on d 0,14 and 28, respectively.

Four wk after the final booster, all the mice were sacrificed after final blood collection from the heart. Mice were immersed into $75 \%$ ethanol for 5 min immediately after sacrifice. Thereafter, the peritoneal cavity was opened, and the spleen was removed from each mouse followed by the recovery of gastric fluid flushed with $1 \mathrm{~mL}$ of phosphate buffered saline (PBS) containing protease inhibitor.

\section{Spleen cell culture}

Immediately after sacrifice, the spleen was aseptically removed from mice and the tissue was minced by syringe and washed twice with RPMI 1640 containing 10\% fecal bovine serum (HyClone Laboratories Inc. Logan UT), $10 \mathrm{mmol} / \mathrm{L}$ Hepes, $100 \mu \mathrm{g} / \mathrm{mL}$ penicillin and $100 \mu \mathrm{g} / \mathrm{mL}$ streptomycin (Sigma, St. Louis, MO). After erythrocyte lysis, splenocytes were separated and cultured in 24-well plates at a density of $1 \times 10^{6}$ cells per well with or without $10 \mu \mathrm{g} / \mathrm{mL} \mathrm{H}$. pylori lysate for $48 \mathrm{~h}$ at $37^{\circ} \mathrm{C}$ and $5 \%$ $\mathrm{CO}_{2}$. The supernatant was harvested on $\mathrm{d} 0,7$ and 14 and stored at $-70^{\circ} \mathrm{C}$ for cytokine assay.

\section{Measurement of serum and gastric antibodies by ELISA}

The gastric fluid sample was centrifuged at $10,000 \times g$ at $4^{\circ} \mathrm{C}$ for $10 \mathrm{~min}$, and the supernatant was obtained for IgA and IgG determination. The measurement of serum anti- $H$. pylori urease B specific IgA, IgG, IgE, gastric IgA and IgG levels was performed by enzyme-linked 
immunosorbent assay (ELISA) using an indirect ELISA as described by Weltzin et al. [13] with some modifications. A 96 well microtiter plate (Costar, Corning Incorporated, Corning, NY, USA) was coated overnight at $4^{\circ} \mathrm{C}$ with $4.0 \mu \mathrm{g} / \mathrm{mL}$ urease $\mathrm{B}$ in carbonate buffer $\left(\mathrm{NaHCO}_{3} / \mathrm{Na}_{2} \mathrm{CO}_{3}\right.$, $\mathrm{pH}$ 9.6) and then free binding sites were blocked with PBS containing $1 \%$ bovine serum albumin (BSA) and $0.1 \%$ Tween 20 (ELISA buffer) for $1 \mathrm{~h}$ at $37^{\circ} \mathrm{C}$. Duplicate serum and gastric fluid samples were diluted in ELISA buffer and incubated for $2 \mathrm{~h}$ at $37^{\circ} \mathrm{C}$. The plates were then incubated with ELISA buffer containing IgA, IgG or IgE antibodies conjugated with horseradish peroxidase (HRP; Serotec, Oxford, England) for $1 \mathrm{~h}$ at $37^{\circ} \mathrm{C}$. Samples were washed five times with PBS containing $0.1 \%$ Tween 20 between each incubation step. Then the plates were developed with tetramethylbenzidine (TMB) to measure the absorbance at $450 \mathrm{~nm}$. The data were expressed as optical density (OD) units.

\section{Determination of cytokines in the cultured splenocyte supernatant}

Single splenic cell suspension was inoculated in vitro with or without $H$. pylori lysate at the concentration of $10 \mu \mathrm{g} / \mathrm{mL}$ in a total volume of $1 \mathrm{~mL}$. The supernatants were collected on d 0, 7 and 14, respectively. Interleukin-4 (IL-4) and interferon- $\gamma$ (IFN- $\gamma$ ) concentrations in the cultured splenocyte supernatant were measured by the mouse ELISA Kit (Jingmei Biotech, Shanghai, China) following the manufacturer's instructions.

\section{Statistical analysis}

All data were analyzed using the ANOVA procedure of SAS system (version 8.2, SAS Institute, Inc., Cary, NC, USA). $P$ values less than 0.05 were considered statistically significant.

\section{Results}

Expression of urease $B$ subunit in $E$. coli

E. coli BL21 (DE3) strain was assayed using SDSpolyacrylamide gels for expression of urease B. As shown in Figure 1, protein of $64 \mathrm{KD}$ was observed followed by Coomassie Brilliant Blue (CBB) R-250 staining, which was well correlated with urease $\mathrm{B}$. The purity of urease $\mathrm{B}$ was measured and the concentration was $0.40 \mathrm{mg} / \mathrm{mL}$. The results of our present study suggest that urease B subunit from $H$. pylori can be obtained through mostly expression in $E$. coli without negative effects and is at least suitable for animal protection experiments in further studies.

\section{Strong antibody responses to recombinant urease B} subunit after its subcutaneous delivery with complete/ incomplete freund's adjuvant

Mice were immunized and boosted with recombinant urease B subunit and freund's adjuvant by subcutaneous

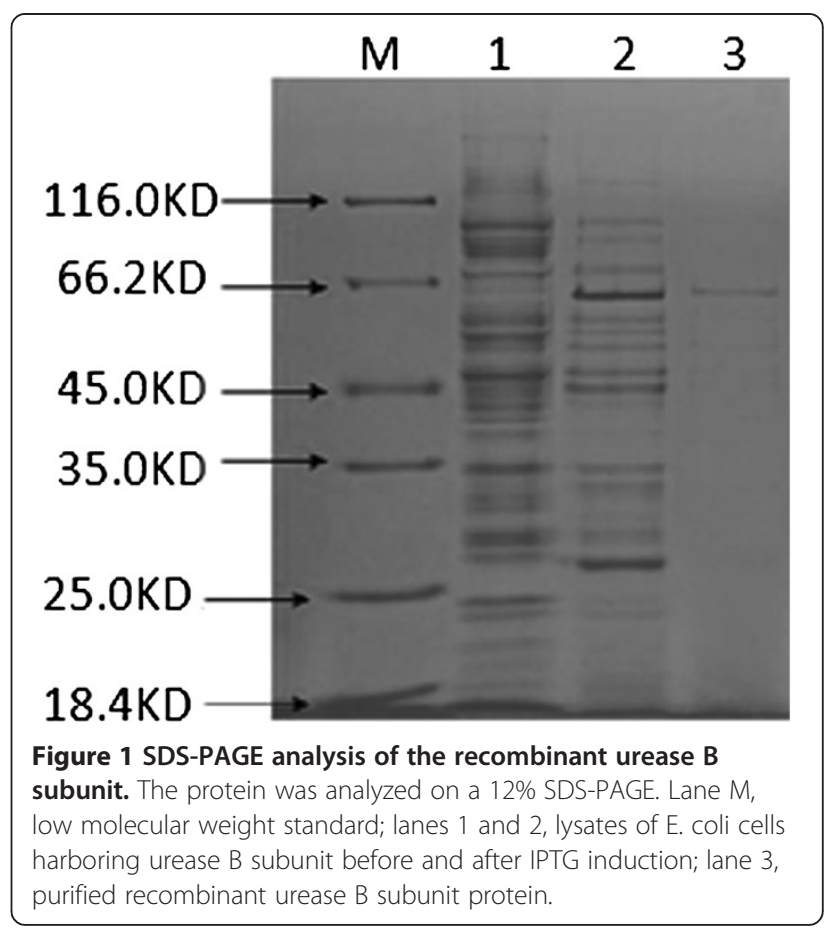

route. To investigate whether urease B subunit expressed by $E$. coli was capable of inducing specific antibody responses and what type of antibody production against urease B was stimulated by systemic immunization, specific IgA, IgE and IgG in the serum and IgA and IgG in gastric liquid were measured by ELISA. It is reported that parenteral immunization tends to induce low levels of secretary IgA but often increase a low level IgE production in most mice [13]. As presented in Figure 2, low levels of serum IgA to urease B were generated by subcutaneous immunization with recombinant urease $B$ subunit, which is consistent with published data [1]. Serum IgE was stimulated slightly with the subcutaneous immunization (Figure 2), but no difference was observed among the three groups.

As shown in Figure 3, IgG specific for urease B was nearly zero in the serum of unimmunized mice. Nevertheless, serum urease B antigen-specific IgG were significantly increased on day 14, 28 and 56 in the antigen immunized group compared with the control and adjuvant injected groups $(P<0.05)$. Furthermore, gastric IgG to urease B subunit antigen was statistically higher $(P<0.05)$ in urease $\mathrm{B}$ antigen-immunized mice than in the control and adjuvantinjected mice (Figure 4), although gastric anti-urease B antigen specific IgA was not influenced among the three groups.

\section{Subcutaneous immunization with recombinant urease B subunit results in elevated Th1/Th2 responses}

Available evidence has revealed that systemic immunization can protect mice against $H$. pylori infection $[1,13,14]$. But it 


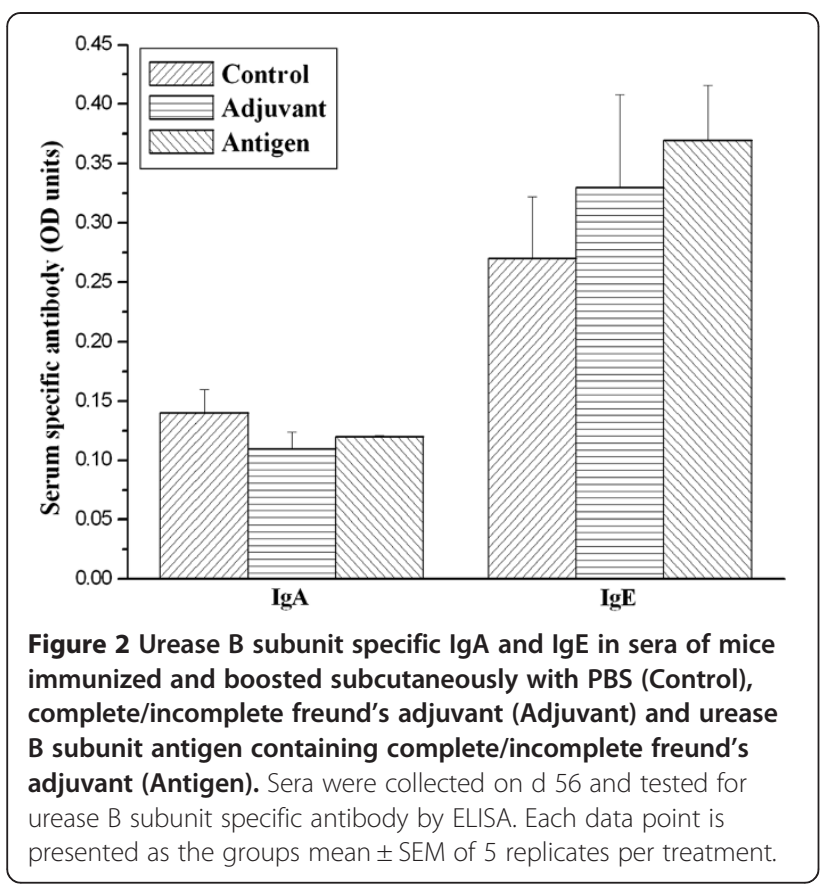

is still controversial whether Th1 cells, Th2 cells or both the two types of cells contribute to the protection. To further investigate the function of Th1/Th2 cells under the conditions of our present study, we determined IL-4 and IFN- $\gamma$ that has been regarded as the two representative interleukins of Th1 and Th2 type immune responses $[15,16]$ to indirectly reflect the function of Th1 and Th2 immune responses in the protection against $H$. pylori infection. As

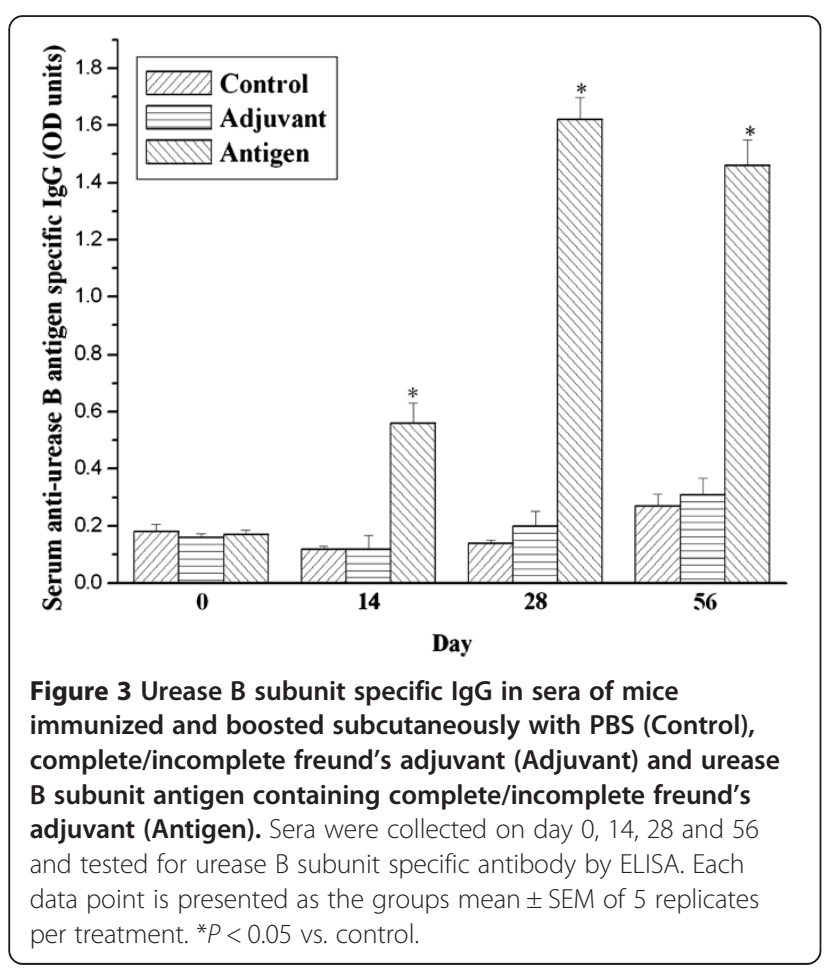

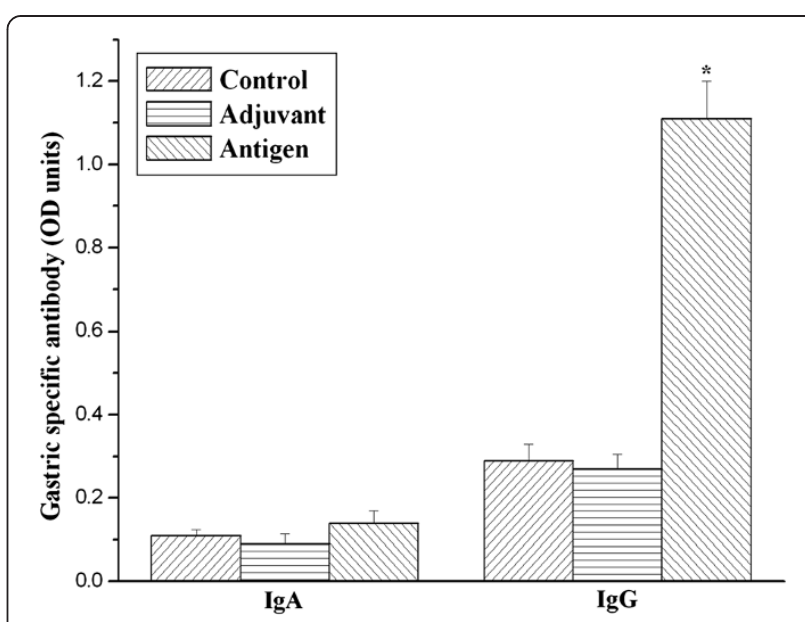

Figure 4 Urease B subunit specific $\lg A$ and $\lg G$ in the gastric liquid of mice immunized and boosted subcutaneously with PBS (Control), complete/incomplete freund's adjuvant (Adjuvant) and urease B subunit antigen containing complete/ incomplete freund's adjuvant (Antigen). Gastric fluid samples were collected on day 56 and tested for urease B subunit specific antibody by ELISA. Each data point is presented as the groups mean \pm SEM of 5 replicates per treatment. ${ }^{*} P<0.05$ vs. control.

shown in Figure 5A, concentrations of IL-4 increased progressively in the supernatant of spleen cell culture of urease $\mathrm{B}$ immunized mice compared to the PBS control and adjuvant control groups $(P<0.05)$. Simultaneously, the production of IFN- $\gamma$ was also enhanced by splenic cells while the concentrations of IFN- $\gamma$ secteted by splenocytes from control mice or adjuvant mice were very low and nearly zero (Figure 5B).

\section{Discussion}

The present study evaluated the effects of $H$. pylori urease $B$ subunit on the immune responses of mice by subcutaneous immunization. Colonization in the stomach mucosa by $H$. pylori causes the incidence of gastrointestinal diseases for adults and children. Although it is easy to prevent the growth of $H$. pylori by antibiotics in vitro, eradication of this bacterium from the infectious stomach of patients is of great difficulty for the existence of antibiotic resistance during therapy as well as reinfection due to the prevalence of infection $[17,18]$. Most investigators have focused on the prophylactic and/or curative immunization using $H$. pylori sonicates or recombinant urease, especially urease $B$ as oral vaccines for the protection against $H$. pylori infection $[1,5,6]$. Considering the infectious objectives by $H$. pylori are the mucosa of gastrointestine, immunization through mucosal routes, such as oral immunization has been widely adopted to trigger and stimulate the immune system underlying the intestinal mucosa in a variety of previous researches which tended to enhance IgA production $[2,5,8]$. Although IgA has been found to play an 

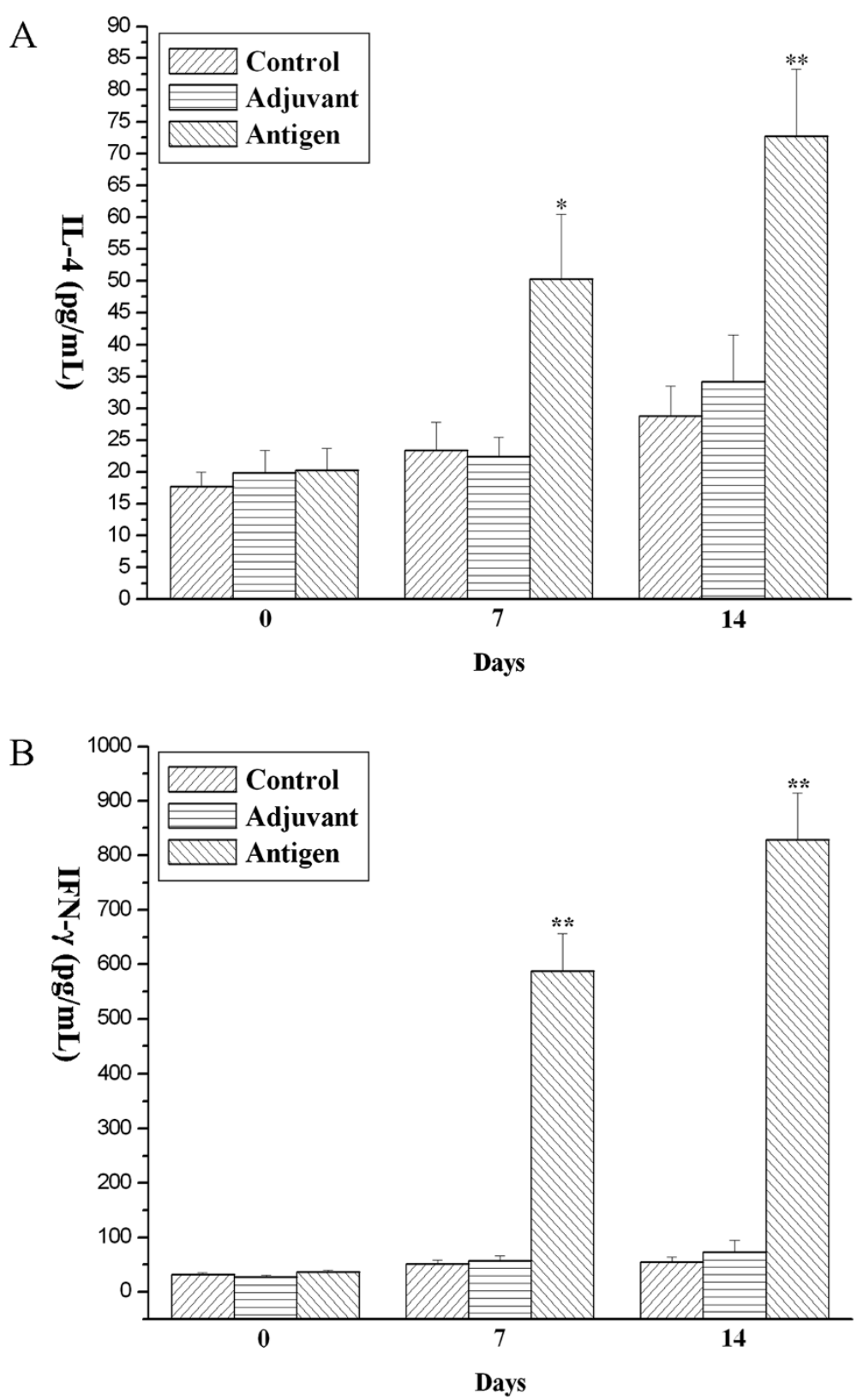

Figure 5 The IL-4 (A) and IFN- $\gamma$ (B) production in H. pylori lysate-stimulated splenocytes at day 0, 7, and 14 after sacrifice from mice immunized and boosted subcutaneously with PBS (Control), complete/incomplete freund's adjuvant (Adjuvant) and urease B subunit antigen containing complete/incomplete freund's adjuvant (Antigen). Each data point is presented as the groups mean \pm SEM of 5 replicates per group. ${ }^{*} P<0.05$ vs. control, ${ }^{* *} P<0.01$ vs. control.

important role in mucosal immunity against invasion by mucosal pathogens, some investigations have demonstrated that secretory IgA is not required for protection of $H$. pylori infection because immunoglobulin-deficient mice can also be protected when lack of antibody responses $[6,11,19,20]$. Consistent with those reports, little or no specific IgA to urease B subunit in gastric liquid was detected in the three groups in the present study.
As mentioned above, one of the major drawbacks of oral immunization is the lower immunogenicity of the ingested foreign antigens which cannot stimulate stronger immune responses in the body unless some adjuvants are used [13]. Compared to oral immunization, parenteral immunization avoids the toxicity and diarrhea caused by the contact of foreign antigens and adjuvants to the intestinal epithelial cells [13]. Furthermore, parenteral delivery of antigens can 
induce much stronger humoral and systemic immune responses. To date, many studies have revealed that parenteral immunization is capable of protecting against $H$. pylori booster better than or as effectively as mucosal immunization [1,11,21-23]. Therefore, subcutaneous immunization was adopted in the present study to evaluate the effects of $H$. pylori urease B subunit in a mouse model.

Although previous publications have shown that antibodies are helpful but not essential for host immune protection [19], antibodies can clear most infections and are beneficial for the host [7]. Even if antibodies play limited role in protection from Helicobacter infection, they are still the markers of immune responses and other arms of immune system may function importantly [7]. It is well known that IgG is the main antibody in the serum stimulated by foreign antigens especially via parenteral immunization [24,25]. In the current study, antiurease IgG antibodies in the serum and gastric liquid were significantly increased indicating that urease B subunit delivered by $E$. coli is highly immunogenic and capable of inducing protection against $H$. pylori. It has been well postulated that IgG is sufficient to confer protection against a variety of infections, including mucosal infectious diseases [26]. The IgG antibody plays an essential role in the local and systemic immune responses during the protection from Helicobacter infection, which has been reported in numerous publications $[6,26,27]$.

It has been well documented that $\mathrm{T}$ lymphocytes can be classified as $\mathrm{CD} 4^{+}$or $\mathrm{CD} 8^{+}$subsets differentiated with their surface markers [28]. Recently, another T lymphocyte subset, that is, Th17 cells has been discovered $[29,30]$. CD4 ${ }^{+} \mathrm{T}$ cells are defined as helper $\mathrm{T}$ cells. Thelper 1 (Th1) cells, Th2 cells and Th17 cells are different types of helper $\mathrm{T}$ cells resulting in the secretion of different patterns of cytokines $[15,29,31]$. Th1 lymphocytes are characterized by the secretion of IL-2, IFN- $\gamma$ and so on, which are vital to cell-mediated immunity, while Th2 lymphocytes are predominantly involved in humoral immunity and allergic responses leading to the production of IL-4, IL-5 and IL-10, etc. [15,16]. Th 17 cells produce IL-17, IL-6, TNF- $\alpha$ and IL-22, etc. [29].

Previous studies have proven that IL-4 is a Th2-type representative cytokine which plays a key role in allergic inflammation [16]. Production of high level of IL-4 may indicate preferential activation of Th2 cells. However, IFN- $\gamma$ is the essential Th1 cytokine that functions reciprocally on the induction of IL-4 [32]. The secretion of Th1/Th2 cytokines may indirectly reflect the balance of Th1/Th2 type immune responses in the body. Gottwein et al. [10] presented that immunization with Helicobacter antigens and Freund's adjuvant induced protective anti-Helicobacter immunity resulting in production of IFN- $\gamma$. The analysis for cytokines in the cultured splenocyte supernatant also showed that concentrations of IL-4 and IFN- $\gamma$ was significantly elevated in the supernatant of spleen cell culture of urease B immunized mice compared to the PBS control and adjuvant control groups, which suggested that Th1/Th2 type responses were both stimulated by the recombinant urease B subunit antigen. Similar results were also obtained by Guy et al. [1] who found that a combination of strong Th1 and Th2 responses induced by urease mixed with adjuvants elicited better protection from $H$. pylori infection than that of a predominantly $\mathrm{Th} 2$ type response.

\section{Conclusions}

The current study demonstrates that recombinant urease B subunit induced higher concentrations of serum and gastric IgG as well as an increase of IL- 4 and IFN- $\gamma$ in splenocytes of the immunized mice by subcutaneous immunization. The application of urease B subunit in parenteral inoculation strategies might enlighten us to use it as the effective component of vaccine against $H$. pylori.

\section{Competing interests}

The authors declare that they have no competing interests in relation to this study.

\section{Authors' contributions}

PS carried out the experiment and drafted the manuscript. JQW conceived the study, participated in its design and coordination, and helped draft the manuscript. YTZ performed the animal experiments. All authors read and approved the final manuscript.

\section{Acknowledgements}

This study was financially supported by National Natural Science Foundation of China (31201824), and by the Agricultural Science and Technology Innovation Program (ASTIP-IAS07), and by Research Program of the State Key Laboratory of Animal Nutrition (2004DA125184G1103).

Received: 18 July 2013 Accepted: 3 February 2014

Published: 22 February 2014

\section{References}

1. Guy B, Hessler C, Fourage S, Haensler J, Vialon-Lafay E, Rokbi B, Millet MQ: Systemic immunization with urease protects mice against Helicobacter pylori infection. Vaccine 1998, 16:850-856.

2. Marchetti M, Aricò B, Burroni D, Figura N, Rappuoli R, Ghiara P. Development of a mouse model of Helicobacter pylori infection that mimics human disease. Science 1995, 267:1655-1658.

3. Thibault A, Marteau P, Drouet L, Slove AL, Sollier CBD, Camus M, Dray X: In vivo effect of proton-pump inhibitors on gastric plasmin-dependent fibrinolysis: a study in a porcine model. Digest Liver Dis 2012, 44:995-998.

4. Kumar KR, lqbal R, Coss E, Park C, Cryer B, Genta RM: Helicobacter gastritis induces changes in the oxyntic mucosa indistinguishable from the effects of proton pump inhibitors. Hum Pathol 2013, 44:2706-2710.

5. Czinn SJ, Nedrud JG: Oral immunization against Helicobacter pylori. Infect Immun 1991, 59:2359-2363.

6. Dubois A, Lee CK, Fiala N, Kleanthous H, Mehlman PT, Monath T: Immunization against natural Helicobacter pylori infection in nonhuman primates. Infect Immun 1998, 66:4340-4346.

7. Bégué RE, Sadowska-Krowicka $H$ : Protective efficacy of recombinant urease $\mathrm{B}$ and aluminum hydroxide against Helicobacter pylori infection in a mouse model. FEMS Immunol Med Microbiol 2010, 60:142-146.

8. Gómez-Duarte OG, Lucas B, Yan ZX, Panthel K, Haas R, Meyer TF: Protection of mice against gastric colonization by Helicobacter pylori by single oral dose immunization with attenuated Salmonella typhimurium producing urease subunits A and B. Vaccine 1998, 16:460-471.

9. Wu C, Zou QM, Guo H, Yuan XP, Zhang WJ, Lu DS, Mao XH: Expression, purification and immune-characteristics of recombination UreB protein of H. pylori. World J Gastroentero 2001, 7:389-393. 
10. Pappo J, Thomas WD, Kabok Z, Taylor NS, Murphy JC, Fox JG: Effect of oral immunization with recombinant urease on murine Helicobacter felis gastritis. Infect Immun 1995, 63:1246-1252.

11. Ermak TH, Giannasca PJ, Nichols R, Myers GA, Nedrud J, Weltzin R, Lee CK, Kleanthous $\mathrm{H}$, Monath TP: Immunization of mice with urease vaccine affords protection against Helicobacter pylori infection in the absence of antibodies and is mediated by MHC-class II-restricted responses. J Exp Med 1998, 188:2277-2288.

12. Weltzin R, Kleanthous $H$, Guirakhoo F, Monath TP, Lee CK: Novel intranasal immunization techniques for antibody induction and protection of mice against gastric Helicobacter felis infection. Vaccine 1997, 15:370-376.

13. Weltzin R, Guy B, Thomas WD, Giannasca PJ, Monath TP: Parenteral adjuvant activities of Escherichia coli heat-labile toxin and its B subunit for immunization of mice against gastric helicobacter pylori infection. Infect Immun 2000, 68:2775-2782

14. Gottwein JM, Blanchard TG, Targoni OS, Eisenberg JC, Zagorski BM, Redline RW, Nedrud JG, Tary-Lehmann M, Lehmann PV, Czinn SJ: Protective antiHelicobacter immunity is induced with aluminum hydroxide or complete Freund's adjuvant by systemic immunization. J Infect Dis 2001, 184:308-314.

15. Carter LL, Dutton RW: Type 1 and Type 2: a fundamental dichotomy for all T-cell subsets. Curr Opin Immumol 1996, 8:336-342.

16. Prescott VE, Hogan SP: Genetically modified plants and food hypersensitivity diseases: Usage and implication of experimental models for risk assessment. Pharmacol Therapeut 2006, 111:374-383.

17. Schutze K, Hentschel E, Dragosics B, Hirscl AM: Helicobacter pylori reinfection with identical organisms: transmission by the patients' spouses. Gut 1995, 36:831-833.

18. Xia HX, Windle HJ, Marshall DG, Smith CJ, Keane CT: Recrudescence of Helicobacter pylori after apparently successful eradication: novel application of randomly amplified polymorphic DNA fingerprinting. Gut 1995, 37:30-34.

19. Blanchard TG, Czinn SJ, Redline RW, Sigmund N, Harriman G, Nedrud JG: Antibody-independent protective mucosal immunity to gastric helicobacter infection in mice. Cell Immunol 1999, 191:74-80.

20. Pappo J, Torrey D, Castriotta L, Savinainen A, Kabok Z, Ibraghimov A: Helicobacter pylori infection in immunized mice lacking major histocompatibility complex class I and class II functions. Infect Immun 1999, 67:337-341.

21. Eaton KA, Krakowka S: Chronic active gastritis due to Helicobacter pylori in immuized gnotobiotic piglets. Gastrienterology 1992, 103:1580-1586.

22. Eaton KA, Ringler SS, Krakowka S: Vaccination of gnotobiotic piglets against Helicobacter pylori. J Infect Dis 1998, 178:1399-1405.

23. Guy B, Hessler C, Fourage S, Rokbi B, Millet MJQ: Comparison between targeted and untargeted systemic immunizations with adjuvanted urease to cure Helicobacter pylori infection in mice. Vaccine 1999, 17:1130-1135.

24. Helm RM, Furuta GT, Stanley JS, Ye JH, Cockrell G, Connaughton C, Simpson P: A neonatal swine model for peanut allergy. J Allergy Clin Immun 2002, 109:136-142.

25. You JM, Li DF, Qiao SY, Wang ZR, He PL, Ou DY, Dong B: Development of monoclonal antibody-based competitive ELISA for detection of $\beta$-conglycinin, an allergen from soybean. Food Chem 2008, 106:352-360.

26. Robbins JB, Schneerson R, Szu SC: Perspective: Hypothesis: Serum IgG antibody is sufficient to confer protection against infectious diseases by inactivating the inoculum. J Infect Dis 1995, 171:1387-1398.

27. Ferrero RL, Thiberge J, Labigne A: Local immunoglobulin $\mathrm{G}$ antibodies in the stomach may contribute to immunity against Helicobacter infection in mice. Gasteroenterology 1997, 113:185-194.

28. Swain S: T cell subsets and the recognition of MHC class. Immunol Rev 1983, 74:129-142.

29. Ciprandi G, Filaci G, Battaglia F, Fenoglio D: Peripheral Th-17 cells in allergic rhinitis: New evidence. Int Immunopharmacol 2010, 10:226-229.
30. Bettelli $\mathrm{E}$, Oukka M, Kuchroo VK: $\mathrm{T}(\mathrm{H})-17$ cells in the circle of immunity and autoimmunity. Nat Immunol 2007, 8:345-350.

31. Chen DY, Hua Q, Mao CM, Jiao ZJ, Wang SJ, Yu LC, Ying X, Dai DF, Yin LJ, Xu HX: Increased IL-17-producing CD4+ T cells in patients with esophageal cancer. Cell Immunol 2012, 272:166-174.

32. Snapper CM, Paul WE: Interferon- $\gamma$ and B cell stimulatory factor-1 reciprocally regulate Ig isotype production. Science 1987, 236:944-947.

doi:10.1186/2049-1891-5-14

Cite this article as: Sun et al:: Evaluating the immune responses of mice to subcutaneous immunization with Helicobacter pylori urease $\mathrm{B}$ subunit. Journal of Animal Science and Biotechnology 2014 5:14.

\section{Submit your next manuscript to BioMed Central and take full advantage of:}

- Convenient online submission

- Thorough peer review

- No space constraints or color figure charges

- Immediate publication on acceptance

- Inclusion in PubMed, CAS, Scopus and Google Scholar

- Research which is freely available for redistribution
C Biomed Central 